\section{Silver Thiosulfate Application Influences Rooting and Budbreak of 'Royalty' Rose Cuttings}

\author{
Wen-Quan Sun and Nina L. Bassuk \\ Department of Floriculture and Ornamental Horticulture, Cornell \\ University, Ithaca, NY 14853
}

Additional index words. ethephon, IBA, Rosa hybrida, spermine

Abstract. The effects of silver thiosulfate (STS) on stored and freshly made cuttings of 'Royalty' rose (Rosa hybrids) were examined in relation to rooting and subsequent budbreak. STS pretreatment at $0.5 \mathrm{~mm}$ during storage stimulated budbreak but decreased the percentage of cuttings that rooted and the number of roots. IBA at 4.9 to $9.8 \mathrm{~mm}$ inhibited budbreak but this effect was partially reversed by STS. Spraying the cuttings with $1.0 \mathrm{~mm}$ STS once daily during the first 5 days of the rooting period also reduced rooting but prevented IBA-induced leaf senescence. Ethephon and spermine, each applied at $0.5 \mathrm{~mm}$ before rooting, had no effect on rooting or budbreak. Chemical names used: (2-chloroethyl)-phosphonic acid (ethephon); indole butyric acid (IBA); N,N'-bis(3-aminopropyl) -l,4-buanediamine (spermine).
The rooting ability of cuttings can vary greatly over the growing season. Storage techniques may allow the grower to harvest shoots when rooting is favorable and to hold them for later use. Successful storage would also facilitate shipping of nonrooted cuttings. Recently, considerable research interest has been shown in the storage of nonrooted leafy cuttings (Andersen and Kirk, 1986; Bartolini and Fabbri, 1988; Briccoli-Bati and Lombardo, 1988; Diaz et al., 1988; von Hentig and Knosel, 1986). One major problem of conventional storage is ethylene accumulation and subsequent deterioration of cuttings (Paton and Schwabe, 1987). Foliar application of silver nitrate and silver thiosulfate (STS) prevented symptoms of ethylene damage during low-temperature storage for leafy cuttings of Pelargonium $\times$ hortorum (Bailey) and extended the storage period of cuttings. However, basal application of STS inhibited subsequent rooting of stored cuttings (Paton and Schwabe, 1987). STS inhibited the action of ethylene and, thus, reduced rooting of Helianthus annuum (L.) cuttings (Liu et al., 1990). Polyamides were recently found to promote root initiation in cuttings (Jarvis et al., 1983; Shyr and Kao, 1985; Tiburcio et al., 1989). Ethylene and polyamides have a common precursor, $\mathrm{S}$-adenosylmethionine (SAM) (Sinska and Lewandowska, 1991). The objective of this study was to improve the rooting and budbreak of rose cuttings following storage. To this end, we investigated the effects of STS on rooting and budbreak of 'Royalty' rose cuttings and examined whether the later application of ethephon (an ethylene-releasing compound) and spermine (a polyamine) would reverse

Received for publication 13 Nov. 1990. The cost of publishing this paper was defrayed in part by the payment of page charges. Under postal regulations, this paper therefore must be hereby marked advertisement solely to indicate this fact. the rooting inhibition induced by STS during prior storage.

Six-year-old stock plants of 'Royalty' rose were grown at $24 / 18 \mathrm{C}$ (day/night) and a 16$\mathrm{h}$ photoperiod in a greenhouse on benches containing a medium of 1 perlite : 1 peat : 1 soil (by volume). Single-node cuttings from nodes 5 to 8 (distal to proximal) were taken, four leaflets per cutting, during Jan. -Apr. 1990. In Expt. A, leaflets or entire cuttings were held $20 \mathrm{~min}$ before storage in a 0.5 $\mathrm{mm}\left(\mathrm{Ag}^{+}\right)$STS solution prepared according to Reid et al. (1980) or in water as the control, and then washed with tap water to remove superficial STS residue. Cuttings were placed into plastic bags and stored for 25 days at $5 \pm 1 \mathrm{C}$ in the dark. Before rooting, the stored cuttings were recut at the base, and the entire cuttings were immersed for 20 $\min$ in an aqueous solution with or without $0.5 \mathrm{~mm}$ spermine and/or $0.5 \mathrm{~mm}$ ethephon $(\mathrm{pH}=3.0$ to 3.2$)$. After drying for 10 to
15 rein, the cuttings were dipped for $10 \mathrm{sec}$ in 4.9 mM IBA or $50 \%$ ethanol as the control. Cuttings were rooted in a medium of 1 perlite : 1 vermiculite $(\mathrm{v} / \mathrm{v})$ under intermittent mist. In Expt. B, newly made cuttings from the same stock plants and nodal position as in Expt. A were treated with or without $9.8 \mathrm{~mm}$ IBA for $10 \mathrm{sec}$ and rooted in $100 \%$ perlite. Cuttings were sprayed until runoff once daily for the first 5 days with $1.0 \mathrm{~mm}$ STS (after the intermittent mist stopped at 11:00 PM). When more than onethird of a leaf was yellow, it was counted as senescent. In both experiments, a completely randomized design was used with five and three replications of 10 to 12 cuttings for Expts. A and B, respectively. Temperature of the rooting media was 20 to $23 \mathrm{C}$, and cuttings were harvested after 20 to 25 days. Rooting percentage and budbreak data were arcsin-transformed before an analysis of variance.

STS application to the entire cutting before storage decreased the proportion of cuttings that rooted (rooting percentage) and root count per cutting, but, remarkably, stimulated budbreak of cuttings in rooting benches. In contrast, an IBA basal dip promoted rooting and inhibited budbreak. The effects of STS and IBA on rooting and budbreak of cuttings were antagonistic. STS partially reversed the inhibitory effect of IBA on budbreak, and IBA increased root production by STS-treated cuttings (Table 1). When only leaflets of cuttings were treated, STS reduced root count but not percent rooting (Table 2); however, it was less effective in stimulating budbreak than was treatment of the entire cutting (Tables 1 and 2). Auxin was previously observed to inhibit budbreak of cuttings (Christensen et al., 1980; Proebsting, 1984). In 'Amanda' rose cuttings, De Vries and Dubois (1988) found that basal application of $>312.5 \mathrm{ppm}(\approx 1.5 \mathrm{~mm})$ IBA significantly delayed and reduced axillary budbreak. In our work, STS stimulated a quick, uniform budbreak. More than $90 \%$ of STS-immersed cuttings broke their buds dur-

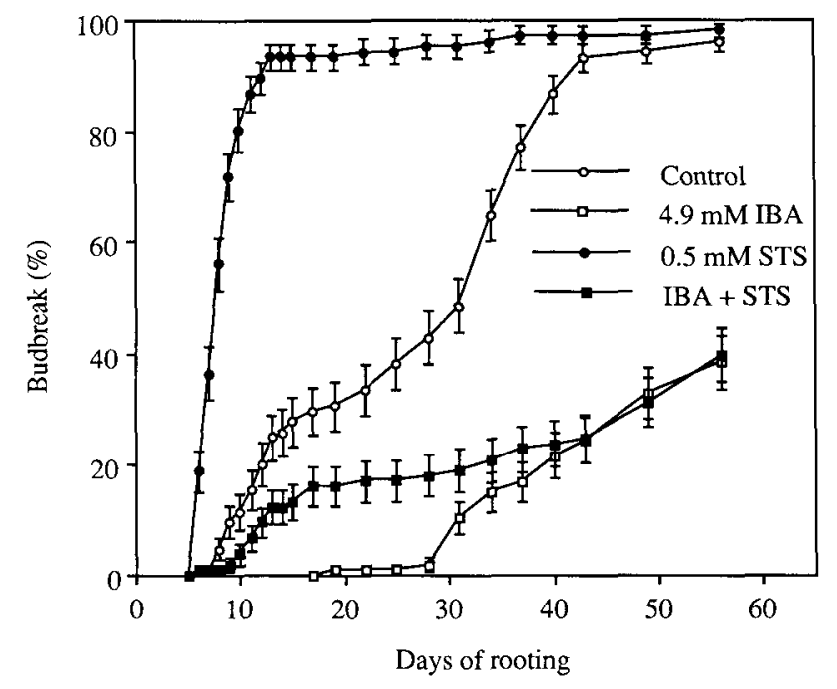

Fig. 1. Budbreak in 'Royalty' rose cuttings after STS and IBA treatments (Expt. A). Bars indicate SE of the mean $(N=120)$. 
Table 1. Effects of STS (0.5 mm and spermine (0.5 mM treatment before storage on rooting and budbreak of 'Royalty' rose cuttings. Cut${ }_{5 \mathrm{C}}$.

\begin{tabular}{lccc}
\hline \hline Treatments & $\begin{array}{c}\text { Rooting } \\
(\%)\end{array}$ & $\begin{array}{c}\text { Roots/ } \\
\text { cutting }\end{array}$ & $\begin{array}{c}\text { Budbreak } \\
(\%)\end{array}$ \\
\hline No IBA & & & \\
Control & 91 & 6 & 36 \\
Spermine & 98 & 7 & 41 \\
STS & 41 & 1 & 96 \\
Spermine + STS & 67 & 2 & 92 \\
4.9 mM IBA & & & \\
Control & 100 & 23 & 2 \\
Spermine & 98 & 23 & 0 \\
STS & 68 & 6 & 17 \\
Spermine + STS & 66 & 4 & 17 \\
Significance & & & \\
IBA & $*$ & $* * *$ & $* * *$ \\
STS & $* * *$ & $* * *$ & $* * *$ \\
Spermine & NS & NS & NS \\
IBA $\times$ STS & NS & $* * *$ & $* * *$ \\
IBA $\times$ spermine & NS & NS & NS \\
STS $\times$ spermine & NS & NS & NS \\
IBA $\times$ STS $\times$ & & & \\
spermine & NS & NS & NS \\
\hline N & & &
\end{tabular}

Ns,*,*****Nonsignificant or significant at $P=$ $0.05,0.01$, or 0.001 , respectively.

$(0.5 \mathrm{~mm})$ on rooting and budbreak of 'Royalty' rose cuttings. Cuttings were examined after 25 days of storage at $5 \mathrm{C}$.

\begin{tabular}{lccc}
\hline \hline Treatments & $\begin{array}{c}\text { Rooting } \\
(\%)\end{array}$ & $\begin{array}{c}\text { Roots/ } \\
\text { cutting }\end{array}$ & $\begin{array}{c}\text { Budbreak } \\
(\%)\end{array}$ \\
\hline Control & 92 & 5 & 42 \\
STS & 83 & 3 & 60 \\
Ethephon & 94 & 5 & 40 \\
STS + ethephon & 88 & 3 & 61 \\
Significance & & & \\
$\quad$ STS & NS & $* * *$ & $*$ \\
$\quad$ Ethephon & NS & NS & NS \\
STS $\times$ ethephon & NS & NS & NS \\
\hline
\end{tabular}

${ }^{z}$ STS applied only to leaflets before storage. Ns, ****Nonsignificant or significant at $P=0.05$ or 0.001 , respectively.

Table 3. Rooting inhibition due to STS sprays on 'Royalty' rose cuttings. ${ }^{2}$ Cuttings were examined after 20 days.

\begin{tabular}{lrc}
\hline \hline Treatments & $\begin{array}{c}\text { Rooting } \\
(\%)\end{array}$ & $\begin{array}{c}\text { Roots/ } \\
\text { cutting }\end{array}$ \\
\hline Control & 63 & 5 \\
$9.8 \mathrm{~mm}$ IBA dip & 100 & 27 \\
$1.0 \mathrm{mM}$ STS spray & 0 & 0 \\
$9.8 \mathrm{mM}$ IBA + 1.0 mM STS & 74 & 8 \\
Significance & & \\
STS & $* * *$ & $* * *$ \\
IBA & $* *$ & $* * *$ \\
STS $\times$ IBA & NS & $* * *$ \\
\hline
\end{tabular}

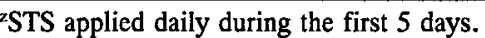

NS,**,***Nonsignificant or significant at $P=0.01$ or 0.001 , respectively.

ing the first 12 days of rooting, while IBAtreated cuttings showed $<40 \%$ budbreak even after 60 days (Fig. 1). The mechanism involved in the budbreak stimulation by STS remains unknown.

Spermine at $0.5 \mathrm{~mm}$ affected neither rooting nor budbreak of rose cuttings and did not improve rooting of STS-treated cuttings (Table 1). Several recent studies, however,

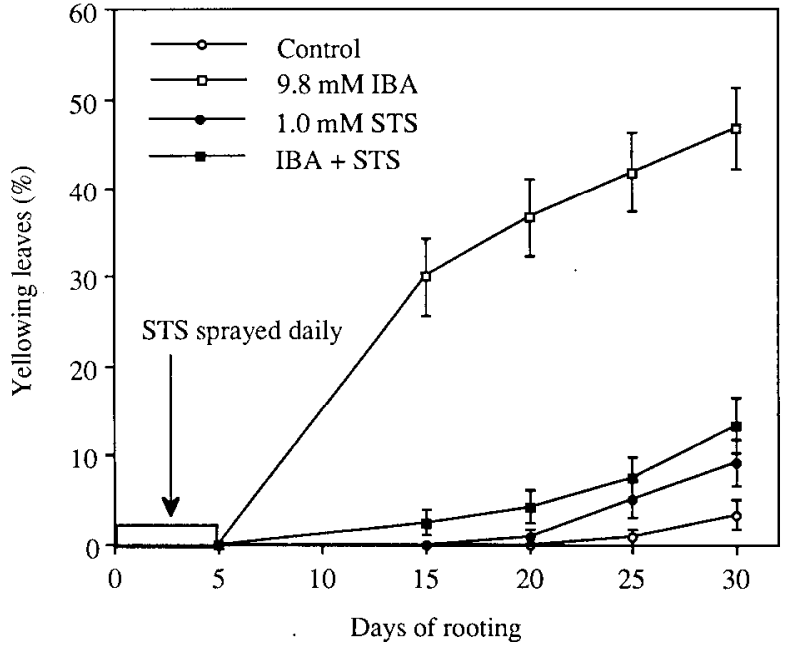

Fig. 2. The percentage of senescent leaves in STS- and IBA-treated cuttings as a function of time (Expt. B). Bars are SE of the mean $(\mathrm{N}=120)$. There was no statistically significant difference between the control, STS, and IBA + STS.

showed that polyamides were involved in root initiation (Biondi et al., 1990; Sankhla and Upadhyaya, 1988; Sun, 1989; Tiburcio et al., 1989). Ethephon applied at $0.5 \mathrm{~mm}$ before rooting also did not influence rooting or budbreak (Table 2). The release of ethylene from ethephon solution is $\mathrm{pH}$-dependent, and the lack of effect maybe due to the low $\mathrm{pH}$ of the solution that we used (Mudge and Swanson, 1978). In another trial with the same material, $5 \mathrm{~mm}$ ethephon resulted in $100 \%$ leaf fall within 6 days, although the $\mathrm{pH}$ of ethephon solution was 3.0 to 3.2 . The lack of response to ethephon in this study was likely a result of the low concentration used.

In Expt. B, STS at $1.0 \mathrm{~mm}$ was sprayed onto the leaflets of cuttings during the first 5 days of the rooting period. STS again inhibited rooting of rose cuttings (Table 3 ) and prevented IBA-induced leaf yellowing, which appeared after 5 days (Fig. 2). Since the control cuttings and those in the IBA plus STS treatment rooted remarkably better than the STS-treated cuttings and without significant difference in leaf yellowing between the three treatments, leaf yellowing could not be explained by translocation of nutrients from leaves for rooting (Table 3 and Fig. 2). Leaf yellowing was probably caused by IBA-induced ethylene synthesis.

In summary, STS can stimulate budbreak and prevent IBA-induced leaf senescence of 'Royalty' rose single-node cuttings. STS at concentrations used in this study, however, reduced root formation. Spermine and ethephone did not reverse STS inhibition of rooting. The response of rose cuttings to various STS concentrations needs further investigation.

\section{Literature Cited}

Andersen, A.S. and H.G. Kirk. 1986. Low pressure storage of herbaceous cuttings. Acta Hort. 181:305-312.

Bartolini, G. and A. Fabbri. 1988. Effects of cold storage and CEPA treatments on rooting of' 140 Ruggeri' cuttings. Acta Hort. 227:257-259.
Biondi, S., T. Diaz, I. Iglesias, G. Gamberini, and N. Bagni. 1990. Polyamides and ethylene in relation to adventitious root formation in Prunus avium shoot cultures. Physiol. Plant. 78:474483.

Briccoli-Bati, C. and N. Lombardo. 1988. Effects of cold storage on rooting olive cuttings. Acta Hort. 227:254-256.

Christensen, M. V., E.N. Eriksen, and A.S. Andersen. 1980. Interaction of stock plant irradiance and auxin in the propagation of apple rootstock by cuttings. Scientia Hort. 12:1117

De Vries, D.P. and L.A.M. Dubois. 1988. The effect of BAP and IBA on sprouting and adventitious root formation of 'Amanda' rose single-node softwood cuttings. Scientia Hort 34:115-121.

Diaz, T., I. Iglesias, and E. Gonzalez. 1988. Influence of cold storage (4C) and of auxin application on the rooting of chestnut cuttings. Acta Hort. 227:272-277.

Jarvis, B. C., P.R.M. Shannon, and S. Yasmin. 1983. Involvement of polyamides with adventitious root development in stem cuttings of mung bean. Plant Cell Physiol. 24:677-683.

Liu, J., I. Mukherjee, and D.M. Reid. 1990. Adventitious rooting in hypotocyls of sunflower (Helianthus annuus) seedlings III. The role of ethylene. Physiol. Plant. 78:268-276.

Mudge, K.W. and B.T. Swanson. 1978. Effect of ethephon, indole butyric acid, and treatment solution $\mathrm{pH}$ on rooting and ethylene level within mung bean cuttings. Plant Physiol. 61:271-273.

Paton, F. and W.W. Schwabe. 1987. Storage of cuttings of Pelargoniurn $\times$ hortorum Bailey. J. Hort. Sci. 62:79-87.

Proebsting, W.M. 1984. Rooting of Douglas-fir stem cuttings: Relative activity of IBA and NAA. HortScience 19:854-856.

Reid, M. S., J.L. Paul, M.B. Farhoomand, A.M. Kofranek, and G.L. Staby. 1980. Pulse treatments with the silver thiosulfate complex extend the vase life of cut carnations. J. Amer Soc. Hort. Sci. 105:25-27.

Sankhla, N. and A. Upadhyaya. 1988. Polyamides and adventitious root formation, p. 202 213. In: T.M. Davis, B.E. Hasaig, and N. Sankhla (eds.). Adventitious root formation in cuttings. Dioscorides Press, Portland, Ore.

Shyr, Y.Y. and C.H. Kao. 1985. Polyamides and rooting formation in mung bean hypocotyl cuttings. Bot. Bul. Academia Sinica 26:179-184. 
Sinska, I. and U. Lewandowska. 1991. Polyamines and ethylene in the removal of embryonal dormancy in apple seeds. Physiol. Plant. 81:5964.

Sun, W.Q. 1989. Path analysis of relationship be- tween the endogenous polyamides and lateral root initiation in apple seedlings. Acta Phytophysiol. Sinica 15:388-392.

Tiburcio, A. F., C.A. Gendy, and K. Tran Thanh

Van. 1989. Morphogenesis in tobacco subepi- dermal cells: Putrescine as marker of root differentiation. Plant Cell Tissue Organ Cult. 19:4354.

von Hentig, W.U. and K. Knosel. 1986. Storage of poinsettia cuttings. Acta Hort. 181:313-322. 